\title{
A TOXIC FRACTION IN THE URINE OF SCHIZOPHRENIC PATIENTS
}

\author{
Mr A. C. DRYSDALE, A.R.I.C. \\ Major R. J. WAWMAN, M.B., Ch.B., D.P.M., R.A.M.C. \\ Surgeon Commander D. H. MARJOT, M.B., B.Ch., D.P.M., R.N. \\ Royal Victoria Hospital, Netley
}

SUMMARY: The isolation of two fractions from schizophrenic urine which proved toxic to the house fly (Musca domestica) is described. Similar fractions from the urine of patients and normal controls produced no such toxicity. Neither fractions contained 3-4 dimethoxyphenylethylamine (D.M.P.E.) (" the pink spot"). The toxic compound in schizophrenic urine is thought to be a glycopeptide.

\section{Introduction}

Harley-Mason (Osmond and Smythies, 1952) suggested that schizophrenia may be associated with abnormal methylation of noradrenaline and the production of a psychotoxic metabolite such as 3-4 D.M.P.E. Friedhoff and Van Winkle (1962) found D.M.P.E. ("the pink spot") in the urine of schizophrenic patients. Takesada, Kakimoto, Sano and Kaneko (1963) and Bell and Sommerville (1966) reported a "pink spot" in the urine of both schizophrenic patients and controls. A " pink spot" was found in the urine of schizophrenic patients and controls by the present authors, but this was not D.M.P.E.

In view of these conflicting findings it was decided to apply a biological test (Bowden and Drysdale, 1965), using the house fly (Musca domestica) to detect toxic fractions in urine. Urines were obtained from physically fit young men of the Armed Forces who were patients or staff at this hospital. The schizophrenic patients were those who required observation and investigation before treatment was started. None of the subjects received drugs until after the urine samples had been obtained.

\section{Method}

Twenty-four hour collections of urine were acidified to $\mathrm{pH} 2$ with concentrated hydrochloric acid and passed down a 2.5 × $30 \mathrm{~cm}$ Zeo-Carb 225 column which was in the acid phase. After washing with distilled water, until a neutral effluent was obtained, the basic components were eluted with $180 \mathrm{ml}$ of ammoniacal ethanol $(20: 80)$. The whole ammoniacal fraction was collected and evaporated to a small volume under nitrogen at $36^{\circ} \mathrm{C}$. All of this concentrate was applied to several sheets of Whatman No. $3(10 \mathrm{~cm}$ and $30 \mathrm{~cm})$ strips of chromatography paper and chromatograms developed by the descending technique for eighteen hours in butanol: acetic acid: water (8: 2: 2). Fractions were located with ninhydrin reagent and two medium running fractions eluted with $0.1 \mathrm{~N}$ hydrochloric acid. These fractions, I and II, were re-extracted on Zeo-Carb 225 as above and subjected to paper chromatography in butanol: acetic acid: water (8: 2:2) and isopropanol: ammonium hydroxide: water $(8: 1: 1)$.

Two main spots appeared when the chromatogram was sprayed with ninhydrinlutidine reagent and heated at $80^{\circ} \mathrm{C}$ for five minutes. The $\mathrm{Rf}$ values in the butanol system were 0.48 and 0.50 and in the isopropanol system 0.39 and 0.52 . Acid hydrolysis of the 
spots from fractions I and II produced amino acids and sugar suggesting that the fractions contained glycopeptides.

A house fly (starved overnight) was placed in a boiling tube, in the bottom of which was a pledget of cotton wool containing water or the substance under test, and the tube plugged with cotton wool. The tubes were placed at five degrees from the horizontal and observed every half hour for eight hours. The observation included moving the tube towards light, passing the hand up and down in front of the tube and tapping the tube.

\section{Results}

Flies fed on fractions I and II from schizophrenic patients often showed a reduction in activity. The affected flies no longer moved, on gentle stimulation, towards the source of light. Flight was less rapid and sustained and, after repeated stimulation, ceased altpgether and the fles clung to the cotton wool plugging the tubes. The flies did not wander about the tube and if they climbed the side often fell off and had difficulty in righting themselves. The main activity was found in fraction II. Water and the fractions from controls did not produce these effects. Fly toxicity was graded as positive $(+)$, equivocal $(+-)$ or negative $(-)$; results are summarised in Table $\mathbf{I}$.

Table I

Summary of fly toxicity

\begin{tabular}{l|c|c|c|c}
\hline \multirow{2}{*}{ Subjects } & \multicolumn{3}{|c|}{ Toxicity } & \multirow{2}{*}{ Totals } \\
\cline { 2 - 5 } & + & +- & - & \\
\hline Schizophrenic patients & 20 & 2 & 9 & 31 \\
Non-schizophrenic patients & & 2 & 6 & 8 \\
Controls & & 3 & 9 & 12 \\
\hline
\end{tabular}

In addition, the flies were fed solutions of neurohormones, psychotoxic compounds and their metabolities up to a concentration of $1 \mathrm{mg}$ per $\mathrm{ml}$. At this concentration the only compounds to affect the flies in a similar way to that noted with fractions I and II were D.M.P.E. and Mescaline. However, neither of these compounds has yet been identified in fractions I and II.

\section{Conclusion}

Glycopeptides have been reported (McGale and Jevons, 1967), as occurring in urine, but these have not been associated with toxic activity in mental disorders. Leach, Byers and Heath (1963) have suggested that the toxic substance " taraxein ", present in schizophrenic serum, is a small peptide molecule similar to bradykinin. Bogoch, Dussik and Conran (1961) showed that alterations in the glycoproteins in cerebrospinal fluid occurred in mental disorders. It is possible that a psychotoxic amine linked to a more complex molecule such as a glycopeptide, or a peptide consisting of amino acids and carbohydrates, is involved in the aetiology of schizophrenia.

\section{Acknowledgements}

We thank Miss M. Davies of Cooper Research Station for supplying the flies and 
Sergeant R. Mitchell, R.A.M.C. and Corporal C. L. W. Masters, R.A.M.C. for their technical assistance.

\section{REFERENCES}

Bell, C. E. and Sommerville, A. R. (1966). Biochem. J. 211, 1405.

Bogoch, S., Dussik, K. T. and ConRan, P. (1961). New Engl. J. Med. 246, 521.

BowDEN, K. and DRYSDALE, A. C. (1965). Nature 206, 1359.

FrIEDHOFF, A. J. and VAN WinkLE, E. (1962). Nature 195, 897.

Leach, B. E., Byers, L. W. and Heath, R. G. (1963). Serological Fractions in Schizophrenia. Hacker Medical Division, Harper \& Row, New York.

McGale, E. H. F. and Jevons, R. R. (1967). Clin. Chim. Acta 17, 44.

OSMOND, H. and SMYTHIES, J. (1952). J. ment. Sci. 98, 309.

TAkeSADA, M., Kaktmoto, Y., SANo, I and Kaneko, Z. (1963). Nature 199, 203

\section{Erratum}

J. roy. Army med. Cps 114, 175

\section{Appointments to The Queen}

After Major-General A. MacLennan for " in succession to Major-General J. Douglas who has retired" read " in succession to Brigadier M. F. H. Kelleher who has retired".

Preliminary Announcement-Corps Occasions for 1969

\section{Provisional dates are as follows:-}

General and Officers Funds, and R.A.M.C. Association 25 April R.A.M.C./R.A.D.C. Swimming Championships 13 June

R.A.M.C. Officers' Dinner (7-30 for 8 p.m.) 26 June

R.A.M.C. Officers' ‘ At Home ’ (4-6 p.m.) 27 June

Corps Sports 28 June

R.A.M.C. Training Centre and Old Comrades Church Parade and 'At Home'

29 June

Corps Golfing Society-Spring Meeting Summer Meeting 17 April Autumn Meeting 30 June 30 Septembe:

R.A.M.C. Non-Medical Officers' Dinner Club 10 October 